IZABELLA KUCHARCZYK

Wydziat Pedagogiki Specjalnej

Akademia Pedagogiki Specjalnej im. M. Grzegorzewskiej

Warszawa

Forum Pedagogiczne

$2017 / 2$

Wpłynęło: 30.03 .2017 Zatwierdzono do druku: 12.05.2017 DOI: 10.21697/fp.2017.2.06

MAGDALENA OLEMPSKA-WYSOCKA

Wydział Studiów Edukacyjnych

Uniwersytet im. Adama Mickiewicza

Poznań

\title{
TRUDNOŚCI SENSORYCZNE A PEŁNIENIE ROLI UCZNIA NA PRZYKLADZIE DZIECI ZE SPECJALNYMI POTRZEBAMI EDUKACYJNYMI
}

Streszczenie: Celem artykułu jest przedstawienie zagadnień dotyczących nieprawidłowości w zakresie przetwarzania sensorycznego u uczniów ze specjalnymi potrzebami edukacyjnymi. Brak właściwej stymulacji dotykowej, przedsionkowej, proprioceptywnej i pozostałych zmysłów wpływa na proces uczenia się i wywiązywania z powierzonych zadań uczniów z SPE. Nieprawidłowa stymulacja sensoryczna potęguje trudności w nabywaniu kompetencji samoobsługowych, koordynacji wzrokowo-ruchowo-czuciowej, umiejętności ruchowych czy integracji odruchów niemowlęcych. Dlatego też należy zadbać o to, aby rodzice, nauczyciele i specjaliści prowadzący różne terapie z dzieckiem ze specjalnymi potrzebami edukacyjnymi wzięli pod uwagę w procesie wychowania aspekt optymalnej stymulacji sensorycznej.

Słowa kluczowe: uczeń ze specjalnymi potrzebami edukacyjnymi, przetwarzanie sensoryczne, trudności sensoryczne, stymulacja sensoryczna.

\section{Wprowadzenie}

Każdego człowieka - dziecko czy dorosłego - cechuje odmienność w zakresie potrzeb indywidualnych. Zależą one nie tylko od cech jednostkowych, takich jak temperament i osobowość, ale także od wpływu czynników tkwiących w środowisku rodzinnym i społecznym (Brzezińska i in. 2014). Sposób zaspokojenia tych potrzeb decyduje o zachowaniu, postępowaniu i działaniu każdej jednostki. 
W przypadku uczniów ze specjalnymi potrzebami edukacyjnym (czyli tych, u których występują trudności uniemożliwiające prawidłowe funkcjonowanie sensoryczne, ruchowe, komunikacyjne, emocjonalno-społeczne) sytuacja się komplikuje. Czas potrzebny do nauczenia się podstawowych umiejętności samoobsługowych i ruchowych u dzieci z SPE jest o wiele dłuższy niż w przypadku dzieci bez dysfunkcji. Wymaga to wielu powtórzeń, odpowiedniej wiedzy ze strony rodziców, ale też i dostosowania się do nich otaczającego je środowiska. Dzięki wymienionym powyżej umiejętnościom dziecko z SPE będzie mogło w przyszłości pełnić role wynikające $z$ bycia uczniem. Będzie mogło poznawać, analizować, przekształcać, interpretować, czyli angażować się w procesy poznawcze i zdobywać wiedzę.

Za proces uczenia się odpowiada mózg. To, w jaki sposób człowiek zareaguje na działające na niego bodźce sensoryczne, werbalne i niewerbalne, zależy głównie od jego umiejętności przetwarzania, analizowania, syntetyzowania, organizowania i interpretowania. Pojawiające się w życiu dziecka choroby, wypadki, uszkodzenia powodują, że sprawności odnoszące się do przetwarzania sensorycznego się obniżają, co przekłada się na jakość osiągnięć szkolnych (por. Biel 2015; Kranowitz 2011; Miller 2015).

W kontekście tytułowej problematyki istotne jest zwrócenie uwagi na to, w jaki sposób dziecko ze specjalnymi potrzebami edukacyjnymi przetwarza informacje sensoryczne. To, czy jest ono nadreaktywne, podkreaktywne, czy jest poszukiwaczem sensorycznym, będzie wpływać nie tylko na jego zachowanie, ale i zachowanie rodziców, a także organizowany przez rodziców i nauczycieli proces edukacyjny i wychowawczy. Świadomość, jak ważna jest odpowiednia stymulacja poprzez ograniczanie lub dostarczanie dużej ilości bodźców sensorycznych, wprowadzanie optymalnej diety sensorycznej ${ }^{1}$ przez rodziców, wpływa nie tylko na zaspokajanie podstawowych potrzeb dziecka z SPE, ale również może wpłynąć na integrację wszystkich członków rodziny (Borowiecka 2010).

Dziecko ze specjalnymi potrzebami edukacyjnymi nie dość, że ma ograniczone możliwości poznawania świata ze względu na występujące u niego choroby, dysfunkcje, niepełnosprawności, to dodatkowo bardzo często nie może zaspokoić swoich potrzeb sensorycznych. Deprywacja lub też nadmiar bodźców może powodować ograniczenia w percepcji otaczającej je rzeczywistości. Jeśli u dziecka występuje niepełnosprawność sensoryczna, intelektualna, ruchowa, specyficzne trudności w uczeniu się, następują opóźnienia w procesie kształtowania się takich umiejętności, jak: czynności samoobsługowe, koordynacja oko-ręka-czucie, orientacja przestrzenna, praksja, percepcja dotykowa, słuchowa, smakowa etc., integracja odruchów, czynności ruchowe, co z kolei może mieć przełożenie na nieradzenie sobie z emocjami, trudności interpersonalne i wreszcie trudności w szkole.

1 Dieta sensoryczna to zaplanowany program działań opracowany przez terapeutę integracji sensorycznej w celu poprawy samoregulacji danej osoby. 
W związku z powyższym, celem niniejszego artykułu jest próba przeanalizowania skutków trudności sensorycznych pojawiających się u dzieci ze specjalnymi potrzebami edukacyjnymi i ich wpływu na pełnienie przez dzieci roli ucznia.

\section{Piramida uczenia się według Williams i Shellenberger i skutki trudności sensorycznych w procesie uczenia się}

Aby dziecko rozwijało się prawidłowo i było zdrowe, ważna jest nie tylko fachowa opieka medyczna, ale także codzienna dbałość rodziców o właściwą stymulację własnych dzieci od najmłodszych lat. Odpowiednia stymulacja ma na celu nie tylko wpływanie na harmonijność rozwoju, ale także na minimalizowanie skutków niepełnosprawności czy deficytów. Aby dziecko mogło przejść przez wszystkie wyróżnione etapy, powinny być spełnione odpowiednie warunki.

Poniżej został zaprezentowany schemat przedstawiający trudności, jakie mogą wystąpić w zakresie przetwarzania danych sensorycznych i ich wpływu na proces uczenia się u uczniów ze specjalnymi potrzebami edukacyjnymi.

Rysunek 1. Skutki trudności sensorycznych a proces uczenia się

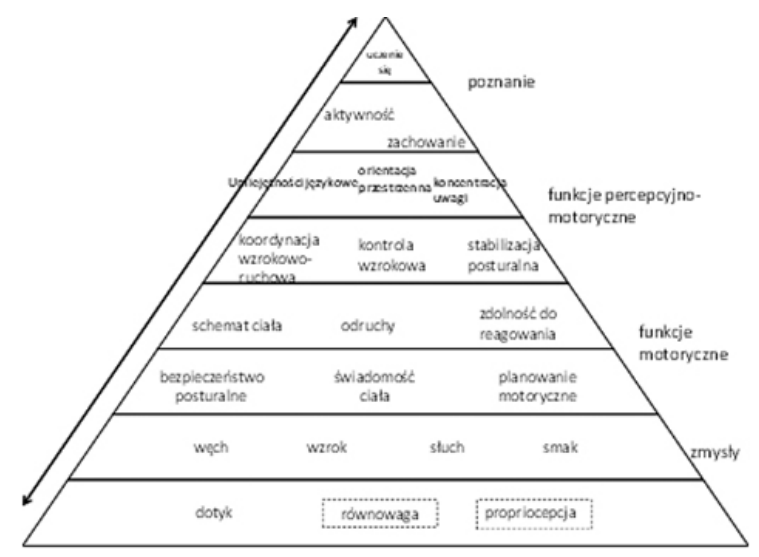

Źródło: opracowanie własne na podstawie Williams, Shellenberger 1996, za: Chuang, Kuo 2016.

Szkoła każdego dnia stawia przez uczniem, zwłaszcza ze specjalnymi potrzebami edukacyjnymi, wiele wyzwań. Musi on poradzić sobie nie tylko z wymogami, ale także z niepełnosprawnością bądź też z chorobą. Według Williams i Shellenberger ${ }^{2}$ (1996, za: Chuang, Kuo 2016), aby dziecko było gotowe do uczenia się, musi być spełnionych kilka wymagań (poziomów). Jeżeli którykolwiek z nich jest nieprawidłowy, proces uczenia się będzie zaburzony, powodując m.in. dysfunkcje, opóźnienia, zahamowanie rozwoju (por. Ayers, 2015; Biel 2015; Farbiszewski, Kranc 2012; Miller 2016; Kranowitz 2011).

2 Williams i Shellenberger (1996) tworząc swoją piramidę ucznia, wzorowali się na czterech poziomach integracji sensorycznej (Ayers 2015). 


\section{Pierwszy warunek - zmysły prawidłowo odbierające, przetwarzające i interpretujące bodźce}

Po pierwsze, proces uczenia się zależy od sprawnego przetwarzania bodźców sensorycznych ze wszystkich kanałów. Etap ten rozpoczyna się już w wieku prenatalnym, kiedy to informacje z poszczególnych zmysłów odbierane są przez receptory, a następnie przetwarzane, analizowane, syntetyzowane, organizowane w mózgu zarówno pojedynczo, jak i grupowo (Eliot 2010). Sprawnie działające zmysły są nierozerwalnie związane $\mathrm{z}$ aktywnościami podejmowanymi przez człowieka. Każdy bodziec rejestrowany przez receptory zostawia ślad pamięciowy w mózgu. Dzięki temu udoskonalają się zdolności percepcyjne i wszelkie mechanizmy sterujące zachowaniem człowieka.

U dzieci ze specjalnymi potrzebami ten pierwszy warunek w dużym stopniu nie jest spełniony, a to dopiero początek drogi we wspinaniu się po szczeblach piramidy uczenia się. I tak na przykład, ze względu na niepełnosprawność słuchu u uczniów tych stwierdza się trudności w zakresie przetwarzania informacji przedsionkowych, proprioceptywnych, dotykowych, co ma duży związek z późniejszym osiąganiem przez nich tzw. „kamieni milowych” i występowaniem opóźnień psychoruchowych (por. Conway i in. 2011; De Kegel 2012; Gursel 2014; Kaga i in. 2008; Martin i in. 2012; Rajendran, Roy 2011; Rine i in. 2000). Badania de Souza Melo i in. (2013) pokazują, że u osób z niedosłuchem odbiorczym mogą występować zaburzenia w zakresie przetwarzania przedsionkowego w wyniku urazów ucha wewnętrznego.

U uczniów z niepełnosprawnością wzroku występują podobne trudności wynikające z niewłaściwej często stymulacji przedsionkowej i proprioceptywnej, takie jak: opóźnienia w opanowaniu umiejętności ruchowych, obniżone napięcie mięśniowe, nieprawidłowy chód, późniejsza kontrola głowy, opóźnienia w zakresie przekraczania linii środkowej ciała, trudności w integracji bilateralnej z powodu braku czucia, trudności w koordynacji, wady postawy (Bouchard, Tétreault 2000; Brambing 2006; Fazzi i in. 2010; Gazzellini i in. 2015; Hallemans i in. 2011; Krzysztofik i in. 2012; Levtzion-Korach i in 2000; Navarro i in. 2004; Prechtl $i$ in. 2001; Rosen 1997; Rutkowska i in. 2016, 2012; Wagner i in. 2013). Osoby z niepełnosprawnością wzroku kompensują sobie brak wzroku głównie zmysłami słuchu i dotyku. Zdaniem Bowden, McNulty (2013), Deshpande i in. (2008), Dinse (2006), Reuter i in. (2012), Tremblay i in. (2003), percepcja dotykowa doskonali się wraz $\mathrm{z}$ wiekiem, dlatego też dzieci te im są starsze, tym mają mniejsze trudności w rozpoznawaniu dotykiem przedmiotów czy czytaniu w języku Braille’a.

Kolejną grupą dzieci ze specjalnymi potrzebami edukacyjnymi, u których stwierdza się trudności sensoryczne, to dzieci z autystycznym spektrum zaburzeń (ASD). U około 42 do 88 proc. osób z ASD stwierdza się zaburzenia procesów sensorycznych w zakresie ich prawidłowej modulacji (por. Rimland 1990). Badania m.in. M. Elwin i in. (2012) pokazują, że dzieci z ASD często cechuje podreaktywność w zakresie propriocepcji, niewłaściwa reaktywność na ból, nadwrażliwość 
dotykowa. Duża grupa osób z ASD cechuje się nadwrażliwością smakową oraz bardzo specyficznym wyborem produktów wpływających na reakcje i zachowanie (por. Bowers 2002). Dzieci te wykazują także nietypowe zachowania w odpowiedzi na bodźce słuchowe. Przykładami takich nietypowych zachowań jest m.in. wkładanie dłoni do uszu, zasłanianie uszu, umieszczanie dłoni nad uszami tylko po to, aby stłumić dźwięk albo go spotęgować. Takie zachowania wynikają przede wszystkim z potrzeby autostymulacji. Dzieci te charakteryzują się również trudnościami w przejściu z jednej aktywności słuchowej do drugiej, co w konsekwencji prowadzi na dekoncentracji i zwiększonego poziomu pobudzenia, a to utrudnia naukę (por. Baranek i in. 2006; Kern i in. 2006; Dunn i in. 2008; Kientz, Dunn 1997; Ozonoff i in. 2015; Tomchek, Dunn 2007). Do tej pory badania nad nadreaktywnością lub podreaktywnością w zakresie przetwarzania sensorycznego opierały się przede wszystkim na obserwacji. Aktualnie do badań w tej grupie wykorzystuje się najnowsze wynalazki XXI wieku z zakresu nauk biomedycznych (Allely 2013), łatwiej więc o dobrą diagnozę. Dodatkowo opisane wyżej trudności sensoryczne negatywnie wpływają na problemy z zakresu motoryki (por. Braadbaart i in. 2012; Dubois 2010; Riquelme i in. 2016; Suarez 2012).

Uczniowie z zaburzeniami, z deficytem uwagi i nadaktywnością, są bardzo specyficzną grupą. Oceniając ich zachowanie należy przede wszystkim się zastanowić, jakie jest podłoże takich reakcji. Czy nadruchliwość i brak koncentracji wynikają z zaburzenia, czy może przyczyną są trudności w modulacji sensorycznej (SMD), może te trudności się łączą, a może nie należy ich ze sobą łączyć? Dysfunkcje w zakresie modulacji, jak i zaburzenia w deficycie uwagi i nadaktywność wpływają na trudności w występowaniu adekwatnej reakcji fizjologicznej, behawioralnej i emocjonalnej, powodując, że reakcje te są niekontrolowane i impulsywne (Greenspan, Wieder 1993). Czasami trudno jest postawić prawidłową diagnozę, gdyż objawy są bardzo podobne: występuje podreaktywność w sferze czuciowej, słaba kontrola impulsów, nieodpowiednie ruchy rąk czy rozpraszanie (Castellanos i in. 1996; Parush i in. 1997; 2007; Reynolds, Lane 2008; 2009; Shochat i in. 2009). U sporej grupy uczniów zaburzenia w zakresie deficytu uwagi i nadaktywność potęgowane są przez zaburzenia SI, powodując, że uczniowie ci są bardzo wrażliwi na działanie bodźców i dlatego tak szybko reagują na zmiany w środowisku (por. Cermak i in. 2010; Dunn 1999; Kaplan i in. 1994; Miller i in. 2001; Miller, Schoen 2012; Schoen i in. 2015).

Kolejną grupą uczniów, u których występują zaburzenia na pierwszym poziomie, są dzieci z chorobą przewlekłą. Ze względu na długotrwałe hospitalizacje uczniowie ci mają ograniczone możliwości ruchowe, co powoduje, że nie mogą zaspokajać swoich podstawowych potrzeb w zakresie stymulacji przedsionkowej czy proprioceptywnej. Często też dochodzi do występowania u nich nadwrażliwości lub podwrażliwości dotykowej ze względu na częste iniekcje (van Campen i in. 2015).

Podsumowując, jeżeli trudności sensoryczne wystąpią na pierwszym etapie w procesie uczenia się, dziecko nie będzie miało właściwej stymulacji, rodzice 
będą koncentrować się w procesie terapii tylko na tym, jak dziecko ze specjalnymi potrzebami edukacyjnymi pracuje podczas zajęć terapeutycznych, będą ograniczać jego rozwój sensoryczny w czasie wolnym, a to może spowodować wystąpienie i spotęgowanie się trudności na gruncie sensorycznym.

\section{Drugi warunek - funkcje motoryczne}

Aby uczeń ze specjalnymi potrzebami edukacyjnymi mógł spełniać wszystkie wymogi stawiane przez szkołę, jego funkcje motoryczne muszą znajdować się na odpowiednim poziomie. Im więcej występuje dysfunkcji i odchyleń, tym więcej trudności pojawi się w procesie uczenia się.

Aby człowiek mógł prawidłowo rozwijać się motorycznie, potrzebne mu jest odpowiednie bezpieczeństwo posturalne, czyli właściwa regulacja postawy. Postawa ciała to nic innego, jak typowe dla każdego ukształtowanie ciała i takie ułożenie kończyn i tułowia, aby możliwe było utrzymanie prawidłowej pozycji stojącej (por. Kasperczyk 2001; Milanowska 2003). Potrzebna jest również zdolność do zmiany postawy dzięki systemowi równowagi, zapewniającemu stabilność. Oprócz układu przedsionkowego do utrzymywania równowagi potrzebny jest sprawnie działający układ proprioceptywny (który czerpie informacje z mięśni, stawów i więzadeł), układ wzrokowy (niezbędny do znalezienia punktu odniesienia), oraz prawidłowo funkcjonujący układ szkieletowo-mięśniowy (somatosensoryczny). Pomiędzy tymi elementami zachodzi ciągłe sprzężenie zwrotne, umożliwiające dostosowanie się do zmiany położenia. Układem, który pełni funkcję regulatora, jest układ nerwowy (układ sterujący) (por. Błaszczyk, Czerwosz 2005). Kontrola ciała i umiejętność utrzymania równowagi to pojęcia o charakterze dynamicznym. Odnoszą się one do umiejętności przeciwdziałania siłom zakłócającym, pochodzących zarówno ze środowiska zewnętrznego, jak i wewnętrznego. Zaburzenia posturalne widoczne są prawie u wszystkich uczniów ze specjalnymi potrzebami edukacyjnymi. Pojawiają się u uczniów z niepełnosprawnością wzroku (Rutkowska i in. 2014, 2015 Zwierzchowska, Gawlik 2006), słuchu (Gursel 2014; Kaga i in. 2008; Rajendran, Roy 2011), intelektualną, z autystycznym spektrum zaburzeń.

Do prawidłowego chodu i umiejętności utrzymywania równowagi potrzebna jest także prawidłowa świadomość ciała i znajomość jego schematu (czyli somatognozja), a także prawidłowe planowanie ruchowe oraz praksje. Te ostatnie mają charakter wyuczony, gdyż rozwijają się i doskonalą w toku ontogenezy. Aby praksje mogły się pojawić, osoba musi mieć zamiar i plan działania. Wymagają sekwencji następujących po sobie płynnych ruchów. Ich nietypową cechą jest to, że nie pojawiają się od razu w odpowiedzi na działające bodźce sensoryczne, a mogą być zapoczątkowane przez procesy emocjonalne czy poznawcze (Górska i in. 2000; por. Szepietowska Misztal 2011; Walsch 2000). W przypadku dzieci ze specjalnymi potrzebami edukacyjnymi często praksje wymagają treningu, powtarzalności i pewnego schematu. Bez dobrej somatognozji, praksji, schematu 
ciała dziecko może mieć opóźniony rozwój psychoruchowy, wolniej będzie uczyć się wchodzić po schodach, będzie mieć trudności z wykonywaniem czynności samoobsługowych (takich jak ubieranie się, mycie, jedzenie), mogą też pojawić się trudności oralne. Takie nieprawidłowości będą wpływały na to, że u dziecka może zaistnieć niechęć do wykonywania podstawowych, ale skomplikowanych czynności szkolnych, np. pisania, które wymaga nie tylko prawidłowego napięcia mięśniowego, ale także odpowiedniego ułożenia palców przy stosowaniu chwytu pisarskiego. Aby praksja mogła wystąpić, potrzebna jest dobra gnozja wzrokowa, wzrokowo-przestrzenna, rejestracja słuchowa bodźców, odpowiednie łączenie danych poznawczych oraz dostosowanie zachowania do wymogów środowiska.

Do prawidłowego funkcjonowania motorycznego i przedsionkowego potrzebna jest jeszcze integracja odruchów niemowlęcych. Pomiędzy tymi wszystkimi elementami zachodzi bardzo ścisła relacja. Zadaniem układów sensorycznych jest dostarczanie danych dotyczących otaczającego świata. Integracja tych informacji jest możliwa tylko i wyłącznie podczas reakcji (ruchowej, emocjonalnej czy werbalnej) w wyniku zapanowania nad własną postawą. Aby kontrola postularna była właściwa, niezbędne są zintegrowane odruchy niemowlęce. Bez nich nie byłoby możliwe rozwijanie wyższych umiejętności, które są uzależnione od ruchu i postawy (Goddard Blythe 2000).

Odruchy niemowlęce to nic innego, jak względnie przewidywalna reakcja (motoryczna-dynamiczna lub statyczna) na określone bodźce (wzrokowe, słuchowe, dotykowe, przedsionkowe, smakowe, węchowe, proprioceptywne). Każde dziecko przychodzi na świat wyposażone w określone odruchy, których zadaniem jest dostosowanie dziecka do funkcjonowania w tym świecie i zaspokojenie podstawowych potrzeb. Odruchy niemowlęce powinny występować przez kilka pierwszych miesięcy po narodzinach, umożliwiając wykształcenie się nawyków kontrolowanych. Po upływie ściśle określonego czasu zanikają/integrują się. Jeżeli tak się nie stanie, zostaną nazwane przetrwałymi i będą miały negatywny wpływ na rozwój psychoruchowy dziecka. Zarówno w naukach medycznych, jak i humanistycznych pojęcie odruchu niezintegrowanego jest poruszane bardzo często, choć jest odmiennie rozumiane. W naukach medycznych odnosi się do uszkodzenia mózgu, w pedagogice czy psychologii to dysfunkcja, która opóźnia prawidłowy rozwój, ale wcale nie musi powodować uszkodzenia mózgu. W niniejszym artykule przyjęto rozumienie pojęcia „niezintegrowany” zgodnie z koncepcją S. Goddarda Blythe (2011).

Z badań przeprowadzonych przez Goddarda Blythe (2011) wynika, że występowanie przetrwałych odruchów tonicznych, takich jak asymetryczny toniczny odruch szyjny, symetryczny toniczny odruch szyjny oraz toniczny odruch błędnikowy (TOB) u dzieci starszych może wpływać na trudności w integracji danych wzrokowych, proprioceptywnych, równoważnych, co ma z kolei przełożenie na postawę ciała, zaburzenia westybularne, pracę gałek ocznych, koordynację wzrokowo-ruchowo-czuciową, tonus mięśniowy, integrację górnej i dolnej części 
ciała. Wyniki te zostały m.in. potwierdzone przez badania prowadzone przez E. Z. Gieysztor i in. (2016). Zdaniem autorek im wcześniej wprowadzi się terapię integracji odruchów niemowlęcych, tym zwiększa się możliwość prawidłowego rozwoju psychoruchowego i zapobiega się trudnościom zarówno w sferze edukacyjnej, jak i poznawczej, społecznej i emocjonalnej. Badania zorganizowane w grupie 409 osób w wieku 9-10 lat w Irlandii przez M. McPhilips i N. Sheehy (2004), McPhillips i in. (2000) pokazują, że występowanie przetrwałego asymetrycznego tonicznego odruchu szyjnego ma znaczący wpływ na występowanie trudności w czytaniu, zwłaszcza u dzieci ze zdiagnozowaną dysleksją.

Z kolei badania S. Masgutowej (2008) pokazują, że ATOS, TOB i MORO ${ }^{3}$ to trzy najczęściej diagnozowane odruchy u osób z ASD. Badania te zostały m.in. potwierdzone przez B. Provost i in. (2007).

$\mathrm{Na}$ temat przetrwałych odruchów w grupie uczniów z niepełnosprawnością słuchu pisali N. Livingstone i M. McPhilips (2014). Przebadanych zostało 25 dzieci z uszkodzonym słuchem powyżej $40 \mathrm{~dB}$ w wieku 6-12 lat. Okazało się, że występujący u tych uczniów asymetryczny toniczny odruch szyjny miał negatywny wpływ na nabywanie przez nich umiejętności ruchowych, zdolności poznawczych i umiejętności czytania. Kolejną grupą ze specyficznymi trudnościami w uczeniu się, u której sprawdzano występowanie odruchów niemowlęcych, są uczniowie z zespołem hiperkinetycznym. Badania potwierdzające występowanie przetrwałych odruchów niemowlęcych w tej grupie prowadzili m.in. Links i in. 2010; Nicolson i in. 2011; Sanders, Gillig 2011; Zafeiriou 2004. Natomiast badania czeskich naukowców, J. Konicarovej i P. Boba (2012), przeprowadzone na grupie 20 uczniów z zaburzeniami z deficytem uwagi i nadaktywności w wieku 8-11 lat, ujawniły, że posiadanie powyższego zaburzenia zwiększa występowanie przetrwałego odruchu Moro i Galanta, które mają przełożenie na trudności adaptacyjne, brak tolerancji zmian, nadreaktywności w zakresie zmysłów: wzroku, słuchu oraz dotyku.

\section{Trzeci warunek - funkcje percepcyjno-motoryczne}

Na trzecim etapie rozwoju umiejętności szkolnych nie tylko dochodzi do integracji danych, ale niezwykle istotna jest właściwa koordynacja wzrokowo-ruchowa, odpowiednia kontrola wzrokowa, orientacja przestrzenna. Jeżeli te podstawowe funkcje będą u uczniów mało wystymulowane, proces ich kształtowania będzie zaburzony i przełoży się to na ponoszenie przez uczniów ciągłych porażek. Każda grupa dzieci ze specjalnymi potrzebami edukacyjnych ma swoją specyfikę. Niezależnie od rodzaju uszkodzeń, dysfunkcji czy niepełnosprawności funkcje te wpływają w ogromnym stopniu na przebieg procesu uczenia się. Nawet jeżeli dziecko będzie mogło skoncentrować się na zadaniu, nie będzie rozpraszało się pod wpływem

3 ATOS (asymetryczny toniczny odruch szyjny), TOB (toniczny odruch błędnikowy ) i MORO odruchy pierwotne powstające w wieku prenatalnym dziecka. 
dystraktorów, to bez dobrej koordynacji wzrokowo-ruchowo-czuciowej ani bez dobrze rozwiniętych funkcji z poziomu drugiego, czyli somtognozji, planowania, praksji, zintegrowanych odruchów nie będzie siedzieć w ławce i kodować informacji, tylko skupi się na reakcjach swojego ciała (m.in. na skutek odbioru bodźców sensorycznych) i przyjęciu odpowiedniej postawy ciała.

Aby proces uczenia się przebiegał prawidłowo, na tym etapie należy jeszcze pamiętać o sprawności językowej. Kompetencje językowe są punktem wyjścia do tego, aby dziecko mogło zdobywać nową wiedzę, dlatego też od momentu urodzenia należy stymulować jego mowę. Jednym z czynników wpływających na rozwój mowy (oprócz dobrze rozwiniętych ośrodków nadawczych i odbiorczych) jest praksja. Jeżeli będzie ona zaburzona, dziecko nie będzie wiedziało, jak ułożyć narząady artykulacyjne, co przełoży się na sposób wypowiadania się (Jodzio 2016). Nie wolno też zapominać o ścisłej relacji między rozwojem sprawności językowych a procesami w zakresie integracji sensorycznej. Ze względu na bliską lokalizację ośrodków mowy i ośrodków ruchowych istnieje bardzo silny związek pomiędzy mową a dostarczeniem właściwej stymulacji przedsionkowej, proprioceptywnej i dotykowej. Zmysły odgrywają też ogromną rolę w rozwijaniu słownictwa czynnego oraz biernego, gdyż dziecko poznając otoczenie, nazywa przedmioty, manipuluje nimi, zdobywa informacje o ich położeniu w przestrzeni, o relacjach przestrzennych, zdobywa wiedzę o otaczającym świecie, ale też uczy się określać cechy poszczególnych przedmiotów.

\section{Czwarty warunek - poznanie}

Jeżeli wszystkie wyżej wymienione warunki są spełnione, możliwa jest samorealizacja, poznawanie świata, podejmowanie aktywności, kontrolowanie własnego zachowania i dostosowanie do oczekiwań środowiska. Jeżeli występują zaburzenia na jakimkolwiek poziomie, cały proces uczenia się będzie utrudniony, a motywacja będzie coraz niższa. Trudności sensoryczne, koordynacja wzrokowo-ruchowa, zaburzenia posturalne, niezintegrowane odruchy niemowlęce wpływają nie tylko na osiągane przez ucznia wyniki, ale także mają ogromny wpływ na kształtowanie się relacji społecznych i poczucie bezpieczeństwa emocjonalnego. Dziecko nielubiące bawić się w gry zespołowe, stroniące od sytuacji, kiedy zostanie przypadkowo dotknięte podczas zabawy, może reagować przesadnie i nieproporcjonalnie do działających bodźców, rozhamowując tym samym swój układ nerwowy.

To, jak dziecko ze specjalnymi potrzebami zachowuje w sytuacjach zadaniowych, będzie się przekładać na podejmowanie przez nie aktywności, ale też i na przetwarzanie danych pod kątem emocjonalnym, radzenie sobie w sytuacjach stresujących. 


\section{Zakończenie}

Organizacja środowiska wychowawczego jest procesem niezwykle złożonym i skomplikowanym. Aby dziecko mogło prawidłowo się rozwijać, musi być spełniony szereg warunków, inaczej w rozwoju dziecka może dojść do potęgowania się dysfunkcji i trudności.

Praca z dzieckiem ze specjalnymi potrzebami edukacyjnymi może być o wiele trudniejsza niż w przypadku dziecka bez dysfunkcji czy niepełnosprawności. Należy uwzględniać nie tylko odpowiednie dla danej osoby metody pracy terapeutycznej, ale też należy pamiętać, że z pozoru mało istotne czynniki, jak bodźce sensoryczne, mogą utrudniać cały ten proces terapeutyczny, hamując go. Terapeuci, nauczyciele oraz rodzice pracujący z takim dzieckiem powinni pamiętać, że jeżeli mózg nie przetwarza sprawnie informacji sensorycznych, również nie będzie prawidłowo sterował zachowaniem się ucznia. To od niego zależy rozwój oraz postępy w edukacji i rehabilitacji.

Aby uczniowie ze specjalnymi potrzebami edukacyjnymi mogli realizować się w roli uczniów, niezwykle istotne jest organizowanie procesu wychowawczego, jak i edukacyjnego w taki sposób, aby była zapewniona dziecku odpowiednia stymulacja ruchowa. Przedstawione badania pokazały, że u części dzieci ze specjalnymi potrzebami edukacyjnymi występują trudności w zakresie przetwarzania danych motorycznych. Jeżeli dziecko nie ma możliwości swobodnego poruszania się, często nie dostarcza sobie stymulacji przedsionkowo-proprioceptywnej. Osoby biorące udział w wychowaniu, terapii i edukacji dziecka powinny zadbać o zmienność ćwiczeń i dostosowywać je do indywidualnych możliwości dzieci. Występująca duża liczba wad postawy, skrzywień kręgosłupa, trudności posturalnych, koordynacyjnych u dzieci z SPE powinny uświadomić specjalistom i nauczycielom, że jest to jeden $z$ ważniejszych problemów we współczesnym świecie. Należy pamiętać, że ćwiczenia ruchowe nie mogą być zastąpione przez najnowsze wynalazki XXI wieku - gry interaktywne, gry z wykorzystaniem tabletu czy komputera.

Wskazane również byłoby zapewnienie dzieciom udziału w odpowiednich zajęciach mających na celu integrację odruchów niemowlęcych (np. Program INPP Sally Goddard Blyte), gdyż jest to jeden z czynników niepozwalających na prawidłowy rozwój. Ze względu na to, że właściwe przetwarzanie sensoryczne jest pierwszym warunkiem, który musi być spełniony, aby proces uczenia się był odpowiedni, niezwykle istotna jest wczesna diagnoza procesów przetwarzania sensorycznego u dzieci ze specjalnymi potrzebami edukacyjnymi. Wczesny proces diagnostyczny pozwoliłby na późniejsze wyeliminowanie trudności wynikających z niewłaściwej stymulacji i na zapewnienie optymalnych warunków rozwoju. 


\section{Bibliografia}

Allely C. S. (2013). Pain Sensitivity and Observer Perception of Pain in Individuals with Autistic Spectrum Disorder. „The Scientific World Journal”, vol. 2013, s. 1-20.

Borowiecka R. (2010). Dziecko w równowadze. Ćwiczenia równoważne i koordynacyjne stymulujace prawidłowy rozwój ruchowym, poznawczy i emocjonalny. Warszawa: Wydawnictwo Centrum Edukacji, Diagnozy i Terapii PsychologicznoPedagogicznej Renata Borowiecka.

Bouchard D., Tétreault S. (2000). The motor development of sighted children and children with moderate low vision. „Journal of Visual Impairment \& Blindness", 94 (9), s. 564-573.

Bowden J. L., McNulty P. A. (2013). The magnitude and rate of reduction in strength, dexterity and sensation in the human hand vary with ageing. „Experimental Gerontology", 48 (8), s. 756-765.

Brambing M. (2006). Divergent Development of Gross Motor Skills in Children Who Are Blind or Sighted. „Journal of Visual Impairment \& Blindnes”, 100 (10), s. $620-634$.

Brzezińska A., Jabłoński I., Ziołkowska B. (2014). Specyficzne i specjalne potrzeby edukacyjne. „Edukacja”, 2 (127), s. 37-52.

Castellanos F. X., Fine E. J., Kaysen D., Marsh W. L., Rapoport J. L., Hallet M. (1996). Sensorimotor gating in boys with Tourette's syndrome and ADHD: Preliminary results. „Biological Psychiatry”, 39 (1), s. 33-41.

Chuang T. Y., Kuo M. S. (2016). A Motion-Sensing Game-Based Therapy to Foster the Learning of Children with Sensory Integration Dysfunction. „Educational Technology and Society", 19 (1), s. 4-16.

De Souza Melo R., Waleska P., Souza R. A., Raposo M. C., Ferraz K. M. (2013). Head Position Comparison between Students with Normal Hearing and Students with Sensorineural Hearing Loss. „International Archives Otorhinolaryngology”, 17 (04), s. 363-369.

Deshpande N., Metter E. J., Ling S., Conwit R., Ferrucci L. (2008). Physiological correlates of age-related decline in vibrotactile sensitivity. „Neurobiology of Aging”, 29 (5), s. 765-773.

Dinse H.R. (2006). Cortical reorganization in the aging brain. „Progress in Brain Research", 157, s. 57-80.

Eliot L. (2010). Co tam się dzieje. Jak rozwijać mózg i umysł w pierwszych latach życia. Poznań: Wydawnictwo Media Rodzina.

Elwin M., Ek L., Kjellin L., Schroder A. (2012). Too much or too little: Hyperand hypo-reactivity in high-functioning autism spectrum conditions. „Journal of Intellectual Developmental Disability", 38 (3), s. 232-241

Fazzi E., Signorini S. G., Lanners J. (2010). The effect of impaired vision on development. W: Dutton G., Bax. M. (red.). Visual Impairment In Children due to Damage to the Brain. London, England: Wiley-Blackwell. 
Gazzellini G., Cocchi E., Finocchietti S., Baud-Bovy G., Gori M. (2015). The audio-motor feedback: a new rehabilitative aid for the developing blind child. $10^{\text {th }} \mathrm{ACM} /$ IEEE International Conference of Human Robot Interaction, Portland, USA (Peer-review articles in conferences).

Gieysztor E. Z., Choińska A. M., Paprocka-Borowicz M. (2016). Persistence of primitive reflexes and associated motor problems in healthy preschool children. Archives of Medical Science.

Goddard-Blythe S. (2011). Jak osiaggá sukcesy w nauce? Uwaga, równowaga i koordynacja. Warszawa: PWN.

Goddard Blythe S. (200o). Early learning in the balance: Priming the first $A B C$. „Support for Learning”, vol. 15 (4), s. 154-158.

Górska T., Grabowska A., Zagrodzka J. (2003). Mózg a zachowanie. Warszawa: PWN.

Greenspan S. I., Wieder S. (1993). Regulatory disorders. W: C. H. Zeanach (red.). Handbook of infant mental health. New York: Guilford Press.

Hallemans A., Ortibus E., Truijen S., Meire F. (2011). Development of independent locomotion in children with a severe visual impairment. "Research in Developmental Disabilities", 32 (6), s. 2069-2074.

Jodzio D. (2016). Dysfunkcje integracji sensorycznej a sprawność językowa dzieci w młodszym wieku szkolnym. Gdańsk: Wydawnictwo Harmonia.

Kaga K., Shinjo Y., Jin Y., Takegoshi H. (2008). Vestibular failure in children with congenital Deafness. „International Journal of Audiology”, 47, s. 590-599.

Konicarova J., Bob P. (2012). Retained primitive reflexes and ADHD in children. „Activitas Nervosa Superior”, 5-4, (3-4), s. 135-138

Krzysztofik M., Hałuszczak P., Kojder S., Flieger G., Głowacka A. (2012). Analiza chodu osób niewidomych. „Aktualne Problemy Biomechaniki”, 6, s. 75-82.

Levtzion-Korach O., Tennenbaum A, Schnitzer R., Ornoy A. (200o). Early motor development of blind children. "Journal of Pediatrics and Child Health", 36, s. 226-229.

Links K. A., Merims D., Binns M. A., Freedman M., Chow T. W. (2010). Prevalence of primitivereflexes and Parkinsonian signs in dementia. „Canadian Journal of Neurological Sciences", 37, s. 601-607.

Livingstone N., McPhilips M. (2014) Primary reflex persistence in children with partial hearing. „Developmental Neuropsychology”, 39 (3), s. 233-247.

Masgutowa S. (2008). Neuro-sensomotoryczna integracja odruchów u dzieci niepetnosprawnych jako skuteczna pomoc $w$ ich codziennym funkcjonowaniu diagnozowanie i korekcyjna praca $z$ dziećmi z MPD, autyzmem i FAS. Artykuł przygotowany na konferencję naukową pt. „Jak skutecznie pomagać osobom niepełnosprawnym?", Sandomierz.

McPhillips M., Hepper P.G., Mulher G. (200o). Effects of replicating primary-reflex movements on specific reading difficulties in children: A randomised, double-blind, controlled trial. „The Lancet”, 355 (12), s. 537-541. 
McPhilips M, Sheehy N. (2004). Prevalence of persistent primary reflexes and motor problems in children with reading difficulties. „Dyslexia”, 10, s. 316-38.

Miller L., Anzalone M., Lane S., Cermak S., Osten E. (2007). Concept evolution in sensory integration: A proposed nosology for diagnosis. „The American Journal of Occupational Therapy", 61 (2), s. 135-140.

Navarro A. S., Fukujima M. M., Fontes S. V., Andra de Matas S. L., Prado G. F. (2004). Balance and motor coordination are not fully developed in 7 years old blind children. „Arquivos de Neuro-Psiquiatria”, 62, s. 654-657.

Nicolson S. E., Chabon B., Larsen K. A., Kelly S. E., Potter A. W., Stern T. A. (2011). Primitive reflexes associated with delirium: a prospective trial. „Psychosomatics”, 52, s. 507-512.

Parush S., Sohmer H., Steinberg A., Kaitz M. (2007). Somatosensory functions in boys with ADHD and tactile defensiveness. „Physiology \& Behavior”, 90 (4), s. 553-558.

Parush S., Sohmer H., Steinberg A., Kaitz M. (1997). Somatosensory functioning in children with attention deficit hyperactivity disorder. „Developmental Medicine \& Child Neurology", 39 (7), s. 464-468.

Prechtl H. F. Cioni G., Einspieler C., Bos A. F. Ferrari F. (2001). Role of vision on early motor development lesson from the blind. „Developmental Medicine \& Child Neurology", 43 (3), s. 198-201.

Provost B., Lopez B. R., Heimerl S. (2007). A comparison of motor delays in young children: autism spectrum disorder, developmental delay, and developmental concerns. „Journal of Autism and developmental Disorder”, 37 (2), s. 321-328.

Reuter E., Voelcker-Rehage C., Vieluf S., Godde B. (2012). Touch perception throughout working life: Effects of age and expertise. „Experimental Brain Research”, 216 (2), s. 287-297.

Reynolds S., Lane S. J. (2008). Diagnostic validity of sensory over-responsivity: $A$ review of the literature and case reports. "Journal of Autism Developmental Disorders", 38 (3), s. 516-529.

Reynolds S., Lane S. J. (2009). Sensory overresponsivity and anxiety in children with ADHD. "The American Journal of Occupational Therapy”, 63 (4), s. 433-440.

Rosen S. (1997). Kinesiology and Sensorimotor Function. W: Blasch B. B., Wiener W. R., Welsh R. L. (red.). Foundations of Orientation and Mobility. New York: American Foundation for the Blind.

Rutkowska I., Lieberman L. J., Bednarczuk G., Molik B., Kaźmierska-Kowalewska K., Marszałek J., Gomez-Ruano M-A. (2016). Bilateral Coordination of Children who are Blind. „Perceptual and Motor Skills”, 122 (2), s. 595-609.

Rutkowska I., Bednarczuk G., Molik B. Morgulec-Adamowicz N., Marszałek J., Kaźmierska-Kowalewska K., Koc K. (2015). Balance Functional Assessment in People with Visual Impairment. „Journal of Human Kinetics”, 48, s. 99-109. Rutkowska I, Bednarczuk G., Skowroński W., Marszałek J. (2014). Ocena zdolności utrzymania równowagi dziewcząt $z$ dysfunkcja wzroku na tle norm dla osób pełnosprawnych. „Szkice Humanistyczne”, t. XIV, 4 (36), s. 71-83. 
Rutkowska I., Stranowska K., Molik B., Bednarczuk G., Koc K., Kaźmierska K. (2012). Porównanie poziomu koordynacyjnych zdolności motorycznych chłopców z dysfunkcjami sensorycznymi i pełnosprawnych. „Postępy Rehabilitacji”, 4, s. 55-62.

Sanders R. D., Gillig P. M. (2011). Reflexes in psychiatry. „Innovations in Clinical Neuroscience”, 8, s. 24-29.

Shochat T., Tzischinsky O., Engel-Yeger B. (2009). Sensory hypersensitivity as a contributing factor in the relation between sleep and behavioral disorders in normal schoolchildren. „Behavioral Sleep Medicine”, 7 (1), s. 53-62.

Tremblay F., Wong K., Sanderson R., Cote L. (2003). Tactile spatial acuity in elderly persons: Assessment with grating domes and relationship with manual dexterity. „Somatosensory \& Motor Research”, 20 (2), s. 127-132.

Van Campen J. Jansen F. E., Kleinrensink N. J., Joëls M., Braun K. P., Bruining H. (2015). Sensory modulation disorders in childhood epilepsy. "Journal of Neurodevelopmental Disorders", 7 (34), s. 1-11.

Wagner M. O., Haibach P. S., Lieberman L. J. (2013). Gross motor skill performance in children with and withoutvisual impairments - Research to practice. „Research in Developmental Disabilities", 34 (10), s. 3246-3252.

Zafeiriou D. I. (2004). Primitive reflexes and postural reactions in the neurodevelopmental examination. „Pediatric Neurology”, 31, s. 1-8.

Zwierzchowska A., Gawlik K. (2006). Korektywa dzieci i młodzieży z dysfunkcjami wzroku lub stuchu. Katowice: Akademia Wychowania Fizycznego.

\title{
SENSORY DIFFICULTIES AND ROLE AS A STUDENT ON THE EXAMPLE OF CHILDREN WITH SPECIAL EDUCATIONAL NEEDS
}

\begin{abstract}
The aim of this article is to present issues related to sensory processing disorders of special needs students. The lack of proper stimulation of tactile, vestibular, proprioceptive and other senses affect the process of learning and ability to perform the tasks entrusted to the students with special needs. Incorrect sensory stimulation increases the difficulty of acquiring self-service competencies, visual-motor-tactile coordination, motor skills, or integration of infant reflexes. It is therefore important to ensure that parents, teachers and specialists who carry out various therapies with children with special educational needs should take into account the aspect of optimal sensory stimulation in education process
\end{abstract}

Keywords: students with special educational needs, sensory processing, sensory difficulties, sensory stimulation.

Izabella Kucharczyk - doktor nauk humanistycznych w dyscyplinie pedagogika, pedagog specjalny (tyflopedagog i oligofrenopedagog), psycholog, terapeuta integracji sensorycznej, 
adiunkt w Zakładzie Terapii Pedagogicznej w Akademii Pedagogiki Specjalnej im. Marii Grzegorzewskiej w Warszawie. Adres e-mailowy: izabella.kucharczyk@gmail.com.

Magdalena Olempska-Wysocka - doktor nauk humanistycznych w dyscyplinie pedagogika, pedagog specjalny (surdopedagog), psycholog, neurologopeda, terapeuta integracji sensorycznej, adiunkt w Zakładzie Specjalnych Potrzeb Edukacyjnych na Uniwersytecie im. Adama Mickiewicza w Poznaniu. Adres e-mailowy: magda.olempska@gmail.com. 